\title{
Financial bootstrapping and social capital: how technology-based start-ups fund innovation
}

\author{
David Smith \\ Nottingham Business School, \\ Nottingham Trent University, \\ Burton Street, Nottingham, NG1 4BU, UK \\ E-mail: david.smith02@ntu.ac.uk
}

\begin{abstract}
Innovation requires more than technological expertise. It is a time consuming activity requiring access to a range of resources including finance. Yet, innovators involved in start-ups rarely have direct access to significant financial resources. Instead, they turn to a variety of forms of financial bootstrapping. Defined as access to resources not owned or controlled by the individual innovator, bootstrapping involves imaginative and parsimonious strategies for marshalling and gaining control of resources. This paper reports on research into bootstrapping using case studies, drawn from biographies of well-known innovators. The study found that bootstrapping was widespread and innovators showed great ingenuity in obtaining finance without recourse to conventional financial institutions. Not only were ranges of bootstrapping techniques employed, the study also provided valuable insights into the importance of social capital, in the form of networks of friends, colleagues and other contacts, in providing innovators with access to bootstrapping finance.
\end{abstract}

Keywords: innovation; finance; start-ups; technical entrepreneurship; bootstrapping; social capital.

Reference to this paper should be made as follows: Smith, D. (xxxx) 'Financial bootstrapping and social capital: how technology-based start-ups fund innovation', Int. J. Entrepreneurship and Innovation Management, Vol. X, No. Y, pp.000-000.

Biographical notes: David Smith is Professor of Innovation Management at Nottingham Trent University. He teaches innovation and design and technology management on undergraduate and postgraduate programmes. His research interests cover a variety of aspects of innovation including: $R \& D$ partnerships, user innovation and technology strategy.

\section{Introduction}

Very little of the literature on innovation is devoted to funding and financial aspects of innovation. The same is not true of entrepreneurship and business start-ups, where finance is normally dealt with in considerable detail. However, attention tends to focus on conventional institutional sources of start-up finance. Informal sources of finance such as business angels have until recently been relatively neglected. This is a recent development and other forms of internal finance have generally failed to attract attention. Unlike conventional forms of start-up finance, 'bootstrapping' has been subjected to very 
limited scrutiny by academic researchers. As one of the few pieces of recent research into bootstrapping noted, 'most references to bootstrapping occur in the 'how to set up a business literature' or are anecdotal in nature' [Harrison et al., (2004), p.308].

The term 'bootstrapping' is used in a number of contexts to refer to success achieved through an individual's own efforts [Harrison et al., (2004), p.310]. In the financial context, Bhide (1992, p.110) refers to bootstrapping as, 'launching new ventures with modest personal funds' and similarly, Winborg and Landström (2001, p.235) refer to 'methods for meeting the need for resources without relying on long-term external finance from debt holders and/or new owners'. While these definitions indicate what bootstrapping is not, they fail to adequately convey the nature and characteristics of this source of finance. Other studies have provided further precision. Freear et al. (1995, p.395) for instance define bootstrapping as, 'highly creative ways of acquiring the use of resources without borrowing money or raising finance from traditional sources', while Van Osnabrugge and Robinson (2000, p.24) describe bootstrapping as, 'the highly creative acquisition and use of resources without raising equity from traditional sources and banks'. They go on to add that it is typically characterised by, 'a high reliance on internally generated earnings, second mortgages, credit cards and customers advances'. In a similar vein, a recent study by Harrison et al. (2004, p.308) describes bootstrapping as, 'imaginative and parsimonious strategies for marshalling and gaining control of resources'. This definition probably comes closest to accurately conveying the nature of bootstrapping because of the emphasis on personal initiative and ingenuity. It also identifies the two forms that bootstrapping typically takes, namely ways of acquiring finance that do not rely on conventional sources of finance and ways of minimising the need for finance in the first place.

If we now know what bootstrapping is, why is it important in business start-up situations where innovation is taking place? The answer lies in the high degree of uncertainty surrounding start-ups which is compounded by the additional uncertainty associated with innovation. Under these circumstances, financial institutions are unwilling to provide financial resources. Allied to this is the risk of loss of control associated with external finance. This is generally a key issue for innovators who, having spent significant sums to protect their intellectual property rights, are often anxious not to see them diluted or lost to others.

This study aims to contribute to our understanding of how innovations are funded. It focuses on innovations developed by individuals rather than corporations, specifically those associated with technology-based start-up situations. The study seeks to identify the range of bootstrapping techniques employed and the factors behind the selection of particular bootstrapping techniques. The link between social capital and particular bootstrapping techniques is also explored.

\section{The literature on financial bootstrapping}

Several researchers including Van Osnabrugge and Robinson (2000) and Van Auken (2005) have highlighted the paucity of research studies into financial bootstrapping. Despite this, bootstrapping continues to be a topic that has attracted comparatively little research interest. One of the first studies to highlight this research gap was by Thorne (1989). Though he did not use the term bootstrapping, preferring the term 'alternative financing' instead, nonetheless, Thorne (1989) described a range of methods by which 
business start-ups obtain resources including, borrowing from suppliers via late or deferred payments, deals with customers, 'free' or low cost labour, non-equity funds, and special relationships with institutions and individuals. It was exactly these sorts of methods that Bhide (1992) was referring to when he used the term 'bootstrapping' to describe the informal ways in which entrepreneurs acquire financial resources.

The decade or so since Bhide's (1992) paper has been marked by a steadily increasing number of research studies into financial bootstrapping (Freear et al., 1995; Van Auken and Neeley, 1996; Winborg and Landström, 1997; Carter et al., 2003; Harrison et al., 2004; Van Auken, 2005; Brush et al., 2006). Significantly, these studies have focused not just on business start-ups, but on technology-based business start-ups which by their nature have involved innovation. Hence, a somewhat limited picture is beginning to emerge of how innovation is funded when undertaken by business start-ups. These studies have generally been small-scale, both Freear et al. (1995) and Van Auken (2005) for instance employing less than 100 respondents, while that of Winborg and Landström (1997) involved just over 250. It is also the case that the studies have been predominantly US based (Freear et al., 1995; Van Auken, 2005; Carter et al., 2003; Brush et al., 2006). Only one study, by Harrison et al. (2004), was undertaken in the UK. Although they have focused on technology-based start-ups, the context has been somewhat narrow with several of the studies confined to the software industry.

Similarly, they have adopted a relatively narrow methodological stance, with a heavy reliance on questionnaire based surveys. As a result, the research has been largely descriptive, identifying the bootstrapping techniques employed at a particular point in the development of a new venture. Only one study (Van Auken, 2005) goes as far as attempting some form of classification of bootstrapping techniques. Harrison et al. (2004, p.328) note that the descriptive nature of much of this research has meant that we know little about the 'process dynamics' associated with bootstrapping. Reliance on questionnaire based surveys has also meant that there has been little scope for exploring the role of bootstrapping techniques in general or the relationship between the techniques employed and other facets of business start-ups such as social capital. Interestingly, one study by Winborg and Landström (1997), while based primarily on a questionnaire survey, does include almost incidentally a short case study. The case study not only reveals the bootstrapping techniques employed, but also provides a valuable insight into the context leading to the selection of particular bootstrapping techniques and highlights the importance of relationships to the acquisition of resources in technology-based start-ups.

The studies that have taken place to date have been fairly modest in their findings reflecting the exploratory and descriptive nature of what little research has taken place. It is clear that financial bootstrapping techniques are common and widely used in business start-ups, whether technology-based or not. Just how widespread is evident from the studies by Freear et al. (1995) and Harrison et al. (2004, p.318) which reported that the proportions of respondents that used at least one method of bootstrapping were $90 \%$ and $95 \%$ respectively. Studies have also shown that bootstrapping is very much a feature of the early stages of venture development [Harrison et al., (2004), p.307] and covers a wide variety of techniques. Freear et al. (1995) found evidence of a total of 32 bootstrapping methods in use, while in the studies by Van Auken (2005) and Harrison et al. (2004), the numbers were only slightly less at 28 and 31 respectively. The sheer number of 
techniques led Harrison et al. (2004) to conclude that bootstrapping is an imprecise construct.

Despite the apparent plethora of techniques covered by the term financial bootstrapping, it is evident that firms actually rely on a small number of methods [Harrison et al., (2004), p.322]. A theme that emerges from several of the studies is the importance of relationships to the effective use of bootstrapping techniques. Freear et al. (1995, p.405) describe relationships and customers as being of 'considerable importance', a view echoed by Harrison et al. (2004, p.321) who describe relationships as 'critical' to successful start-ups. Harrison et al. (2004, p.321) go on briefly to explore why this is the case, noting that social capital in the form of personal networks is, 'a prerequisite for the successful exploitation of these bootstrapping techniques'. However, they note that the key in understanding the role that networks play lies in the 'process dynamics' associated with business start-ups, something which is unfortunately beyond the scope of their study. Another study that placed considerable emphasis upon the importance of social capital was that undertaken by Carter et al. (2003). However, while this study provided valuable insights into the nature of social capital [Carter et al., (2003), p.6], because it focused primarily on access to equity capital, unfortunately, it shed little light on the use of bootstrapping.

\section{Methodology}

Given that earlier studies have noted the importance of relationships and social capital in understanding financial bootstrapping, this study seeks to explore both of these aspects, but from the perspective of what Harrison et al. (2004, p.321) term 'process dynamics'. In order to get at these dynamics, something other than the survey approach used in most studies of bootstrapping to date is required. In particular, it is necessary to examine the context in which bootstrapping techniques are employed. Since the context changes over time, this points to a longitudinal rather than a cross-sectional research design and one way in which this can be achieved is through the use of case study research, which can be particularly effective in showing how the context influences the decision-making process.

Case studies provide scope for a detailed in-depth examination of the funding process and in this study, three case studies are employed, each based on a technology-based start-up. The start-ups are Lotus Cars, Oxford Instruments and Dyson Appliances. Each came about through the efforts of a single innovator; hence, they are examples of what Jones and Conway (2004, p.87) term the 'heroic' model of innovation, where an individual develops an innovative new product and then builds a successful business around it. In this instance, the innovations were lightweight sports cars, superconducting magnets and the bagless vacuum cleaner, and the respective innovators, Colin Chapman, Martin Wood and James Dyson. Because they created highly successful businesses and over time became relatively well-known, there is a substantial amount of documentary material, in particular, biographies and business histories covering the individuals and their innovations. For this study, two biographies were used, Gerard Crombac's biography of Colin Chapman (Crombac, 2001) and James Dyson's autobiography Against the Odds (Dyson, 1997), together with Audrey Wood's business history of Oxford Instruments (Wood, 2001), the company created by Martin Wood. The latter comes very close to being a biography. Written by Martin Wood's wife who was one of 
the co-founders of Oxford Instruments, it provides a detailed first hand account of the venture, very much in the style of a biography.

Although the use of biographies as a major data source for case studies is comparatively rare in management research, Roberts (2002) notes that biographical research is used in many disciplines. In the context of management research, Jones and Conway (2004, p.89) observe that autobiographies as 'first hand accounts' are no less valid than in-depth interviews. Similarly, Bryman and Bell (2003, p.406) identify biographies as a potential data source for management researchers citing studies of General Motors (Martin and Siehl, 1983) and Disney (Bryman, 1995). While they note that biographies have to be treated with caution as they may be exercises in reputation building, nonetheless, they suggest that quotations, stories and what they term 'snippets' [Bryman and Bell, (2003), p.406] can be valuable in building case studies.

\section{Case studies}

\subsection{Lotus}

Colin Chapman was one of the most innovative car designers of the post-war era. Among a string of innovations that he produced were a series of lightweight sports cars in the 1950s and when he moved into Formula One motor racing in the 1960s, he created the Lotus 25, the first monocoque construction Formula One car that dispensed with the need for a separate chassis. It was not only a highly successful design that brought Lotus the Formula One world championship, it forms the basis of Formula One car design to this day.

Lotus was founded in 1952 by Colin Chapman with £25 borrowed from his fiancée Hazel Williams [Crombac, (2001), p.35]. Chapman at this time was employed by the British Aluminium Company as a structural engineer and he worked for Lotus in the evenings and at weekends. The company's first premises were former stables leased at a very modest rent from Chapman's father who owned the pub next door [Crombac, (2001), p.34]. This was not the only financial help that Chapman received from his father. Three years later, Chapman senior purchased an adjoining piece of land and loaned it to the company to enable the premises to be extended. When by 1959 the growth of the company meant that even these premises were insufficient, it was Chapman senior who purchased an entirely new site in Cheshunt on which a purpose built factory was constructed.

Colin Chapman was helped in his new venture by a group of volunteers. Most, like Mike Costin who went on to found the engine manufacturer Cosworth, worked for nothing but the promise that they would occasionally get to drive the cars built by the company [Crombac, (2001), p.53]. Lacking much in the way of equipment, Chapman subcontracted the manufacture of the aluminium body of his first sports cars to Williams and Pritchard [Lawrence, (2002), p.40], a small engineering firm also based in North London. Such was the state of Lotus's finances that it was not unusual for Williams and Pritchard to have to chase Chapman in order to get their invoices paid [Lawrence, (2002), p.41].

During the early years, the fledgling Lotus Company benefited from relationships with a variety of institutions. In the early stages, the 750 Motor Club was particularly important. Chapman was a member of the club and participated in many races organised 
by it. Many of the acquaintances that Chapman made through the club were customers for early Lotus sports cars including Gerard Crombac himself. However, not all Chapman's 750 Motor Club customers paid cash, for Lotus was prepared to barter its products in exchange for services [Crombac, (2001), p.35] as when one Patrick Stephens handled Lotus's advertising in exchange for components for his car. Another important institution in the early years was the aircraft manufacturer De Havilland based near to Lotus at Hatfield. Several De Havilland employees, such as Mike Costin [Crombac, (2001), p.42] worked for Lotus in the evenings and at weekends and it was through them that Lotus gained unofficial access to the plane maker's wind tunnel for prototype testing.

By 1955, with expanded premises and a healthy order book, Lotus was sufficiently well established for Colin Chapman to give up his day job at British Aluminium and work at Lotus full time. By 1959, continued expansion meant a move to new premises as the company began production of the Lotus Elite sports car, an innovative design that made extensive use of glass fibre. By this time, Lotus was a recognised car manufacturer, albeit on a small-scale and two years later, Chapman began to work on his most significant innovation, the Lotus 25 Formula One car.

\subsection{Oxford Instruments}

Martin Wood has been described as 'the pioneer of the Oxford entrepreneurial revolution' [Hague and Holmes, (2006), p.1]. He and his wife Audrey founded Oxford Instruments in 1959 with $£ 200$ of their own money. They began producing equipment for research laboratories and pioneered the development of superconducting magnets. At the time, Martin Wood worked for Oxford University as a senior research officer at the Clarendon Laboratory [Wood, (2001), p.4], a leading centre for research into magnetic fields. The main purpose of the new company was the construction of electro-magnets for universities and other bodies establishing similar laboratory facilities. The company's premises were initially the garden shed at the Wood's home in Oxford. What little equipment the company needed was generally borrowed from the university and its only employee was a retired laboratory technician from the Clarendon Laboratory who worked part time. Among the company's first customers were research laboratories at Malvern and Harwell that Martin Wood knew through his work at the university. However, not long after Oxford Instruments had been established, Martin Wood, while attending a conference in the US as part of his work for the university, became aware of new research into superconducting magnets - which were able to generate magnetic fields higher than anything seen before while using much less electrical power. Learning of these developments, Martin Wood set out to make one of these new magnets for himself. Using Oxford University's computer, Wood was able to design a superconducting magnet. To make it, Wood ordered a small quantity of nobium zirconium wire and borrowed a winding machine from the Clarendon Laboratory together with a glass cryostat containing liquid helium - essential to cool the magnet and give it superconducting properties. Early in 1962, Oxford Instruments was able to demonstrate the first superconducting magnet outside the US [Wood, (2001), p.23].

Wood described his new magnet in an article in the New Scientist and demonstrated it at a number of exhibitions including one organised by the Physical Society [Wood, (2001), p.24]. These generated much interest and Oxford Instruments gained its first two contracts to design and build superconducting magnets. By now, the company had acquired larger premises in the form of former stables in Oxford and some second-hand 
manufacturing equipment including an old lathe bought at auction [Wood, (2001), p.11] and early in 1963, the company delivered its first superconducting magnet. In the same year, the company also acquired its first full time employee [Wood, (2001), p.28], while Martin Wood's wife Audrey handled the paperwork. As yet, the new company's financial needs had been met by the Wood's themselves supplemented by loans from family members [Wood, (2001), p.31].

During the 1960s, Oxford Instruments pioneered the development and supply of superconducting magnets in Europe and the company grew rapidly. It soon outgrew the old stables and moved into a former laundry. Having initially purchased supplies of liquid helium from the Clarendon Laboratory, this soon proved an inadequate source of supply and unable to obtain sufficient liquid helium from commercial sources, Oxford Instruments formed a subsidiary to produce its own supply. The increased availability of liquid helium nationally led to a surge in orders for superconducting magnets. By September 1965, the company had a turnover of $£ 94,000$ [Wood, (2001), p.39] and 25 full time employees, but the only external funding was an overdraft from the bank and Martin Wood was still working full time for Oxford University, though the company had appointed a managing director to provide day-to-day control over the business.

\subsection{Dyson}

James Dyson is the inventor of the 'bagless' vacuum cleaner. Launched in July 1993, in a little over two years, the 'dual cyclone' vacuum cleaner produced by his company Dyson Appliances had become the UK’s best selling vacuum cleaner [Dyson, (1997), p.225]. However, successful innovation did not come easily. Dyson was a graduate of the Royal College of Art who had worked on a number of innovations before he became interested in vacuum cleaners. He worked for an entrepreneur, Jeremy Fry developing a new form of boat, before deciding to branch out on his own to develop a new type of wheelbarrow. Called the 'ballbarrow', Dyson set up his own manufacturing company in a venture with his brother-in-law in the 1970s [Dyson, (1997), p.79] in order to produce it. Despite a lack of business knowledge, this innovation proved remarkably successful. It was this venture that indirectly led to Dyson's interest in vacuum cleaners. While instaling dust extraction equipment at the ballbarrow plant, he had the idea of applying the same principle behind the industrial dust extractor to a vacuum cleaner. Unable to persuade his fellow directors, Dyson left to set up a new venture. This time, he went into partnership with his former boss Jeremy Fry, raising his own share through selling part of his garden and mortgaging his house, in order to set up the Air Power Vacuum Cleaner Company. Building prototypes in his garage at home, it took Dyson three years to develop and patent an effective prototype, during which time, he was supported by his family. By this time, he was further in debt so to re-coup his investment as rapidly as possible, he tried to licence his 'dual cyclone' technology.

Unable to persuade the major vacuum cleaner manufacturers in Europe and the US to take out a licence, Dyson eventually turned to Japan and after three years of trying, a Japanese company eventually decided to take up a licence. Developed as a highly priced cleaner called the G-Force [Dyson, (1997), p.162] specifically for the Japanese market, it achieved a modest degree of success and was followed by a similar deal with a Canadian company, but Dyson was plagued by litigation involving would-be licencees. Though the income from licences enabled Dyson to clear his debts and even employ a small staff of 
his own, it was not until 1991 when the litigation was finally settled that Dyson was able to turn his attention to the home market (Dyson, 1997). With his technology proven and a favourable response from consumers [Dyson, (1997), p.188] courtesy of his licence deals, Dyson chose to set up on his own. However, unable to obtain capital from merchant banks or government agencies, he turned to his family again and they agreed to him mortgaging both the family homes to raise $£ 600,000$. By 1993, everything was in place and in July of that year, the Dyson DC01 bagless vacuum cleaner went on sale in the UK.

\section{Case analysis}

All three cases are examples of technology-based start-ups and in each instance, financial bootstrapping techniques are much in evidence in the early stages of the venture. The bootstrapping techniques used were the same or similar to those found in earlier studies, although not unsurprisingly the software specific techniques found in studies undertaken in the software industry such as that by Freear et al. (1995) were not in evidence. Using the categories of bootstrapping identified by Thorne (1989), Table 1 gives an overview of the bootstrapping techniques found in the three case studies.

Borrowing from suppliers and service providers was evident in all three cases, but took a variety of different forms. Chapman was notorious for borrowing from suppliers by delaying payment and suppliers in turn on occasions resorted to re-possessing items they had supplied [Crombac, (2001), p.44]. Dyson on the other hand thrashed out a deal with the firm that made the tooling for the ballbarrow whereby he paid them in instalments [Dyson, (1997), p.186]. However, it is also striking that in two out of the three cases, this was not the only form of borrowing. Chapman borrowed equipment such as De Havilland's wind tunnel, while Wood borrowed a variety of forms of equipment including a computer, a winding machine and cryostats from his employer, Oxford University.

Table 1 Bootstrapping techniques in use

\begin{tabular}{lccc}
\hline Bootstrapping categories & Lotus & Oxford Instruments & Dyson \\
\hline Borrowing from suppliers & $*$ & $*$ & $*$ \\
Deals with customers & $*$ & $*$ & $*$ \\
'Free' or low cost labour & $*$ & $*$ & $*$ \\
Special deals for space & $*$ & & $*$ \\
Non-equity funds & & $*$ & $*$ \\
Special relationships & $*$ & $*$ & \\
Other & $*$ & $*$ & \\
\hline
\end{tabular}

Source: Case studies

Deals with customers, as the Lotus case shows, were something that Chapman made extensive use of, mainly in the form of taking payment in kind. That the others did not use this technique was probably a function of the markets they served, where there simply was not scope for deals with individual customers. Free or low cost labour on the other hand was much in evidence in all three cases. The sources of such labour were varied. All three innovators used their wives as a source of free labour and in the case of both Lotus and Oxford Instruments, their roles were not insignificant as they had 
responsibility for administrative matters. Martin Wood was also able to draw on retired technicians from the Clarendon Laboratory, while Colin Chapman drew on a band of unpaid volunteers recruited mainly through the 750 Motor Club. Special deals for space also cropped up in all three cases, though the nature of the deals varied. Colin Chapman had the use of a stable building behind his father's pub at a low rent, while Martin Wood started in his garden shed and James Dyson used the outbuildings of his home near bath. They may not have begun in garages, as in Silicon Valley where many innovative high-tech businesses, including Hewlett-Packard and Apple Computer, began in garages [Audia and Rider, (2005), p.6], but all three of the case study companies used something very similar. Thorne's category of non-equity funds covers funding obtained from government agencies at national, regional or local levels. Interestingly, not one of the cases studies documents any of the innovators gaining funding of this sort. This may well be a contextual factor. All three of the case studies are UK based and certainly at the time when two of the three cases took place, government agencies in the UK, particularly at the local and regional level, did not provide financial support for innovation.

Special relationships, the sixth form of bootstrapping, were much used in evidence in all three cases and the nature of the relationships provides a valuable perspective on the importance of social capital for start-ups. It was particularly striking that these relationships, which constituted the personal networks of the innovators, were derived from different institutions. Some were family-based, some were university-based, some were industry-based and some were based on social activities. All three innovators had middle class backgrounds and it is striking that family relationships, including parents and in-laws, were an important source of funding. Thus, Colin Chapman's father who was a publican provided his son with premises at a below market rent, Martin Wood's parents who had a professional background provided loans, while James Dyson, whose father was a teacher but who died while he was a boy, gained financial support from his brother-in-law.

While all three innovators were graduates, it was in fact only Martin Wood and James Dyson who appeared to have benefited from university contacts. In Martin Wood's case, university contacts provided both suppliers and customers as well as access to knowledge and expertise about the technology that he was using. In James Dyson's case, it was contacts generated through the Royal College of Art where he had been a student that provided him with a partner when he set out to develop his cyclone technology as well as employees at a later stage [Jones and Conway, (2004), p.98]. Industry-based networks were also shown to be important in at least two of the cases. Colin Chapman benefited from being located near to the aircraft manufacturer De Havilland, which provided him with skilled volunteers as well as access to wind tunnel facilities. In Dyson's case, it was industrial contacts made while developing the ballbarrow that provided him with component suppliers for his vacuum cleaner [Dyson, (1997), p.186; Jones and Conway, (2004), p.98]. Finally, the category of 'other methods' includes a few additional forms of bootstrapping. Both Chapman and Wood used second-hand equipment bought at auction as well as relying heavily on evening and weekend working. Indeed, it is significant that two of the three innovators did not quit their day jobs until their start-ups were very well established. 


\section{Conclusions}

This study provides further evidence that financial bootstrapping techniques are an essential feature of business start-ups, particularly ones based around technological innovation. The cases not only show that many of the bootstrapping techniques identified in earlier survey research are widely used in practice, but they also show in some detail how and why they are used. In so doing, they shed some light on what Harrison et al. (2004) describe as the 'process dynamics' surrounding the use of bootstrapping techniques. However, perhaps the most significant contribution of this study is the insight that it provides into the nature and importance of the personal networks, comprising friends, colleagues and other contacts, which play a crucial role in providing the innovator with access to many of the bootstrapping techniques. The case studies show that these are not confined to 'special relationships', for other bootstrapping techniques, notably borrowing from suppliers and others and free/low cost labour, were also dependent on personal networks. Burt (1992) and others (Sørheim, 2003) have shown how these networks constitute 'social capital' through which individuals access resources. The cases in turn show that this is very much the case with start-ups based on innovation, where innovators' social capital is a key feature of their ability to access financial resources based on bootstrapping techniques.

\section{References}

Audia, P.G. and Rider, C.I. (2005) 'A garage and an idea: what more does an entrepreneur need?', California Management Review, Vol. 48, No. 1, pp.6-28.

Bhide, A. (1992) 'Bootstrap finance: the art of start-ups', Harvard Business Review, November-December, Vol. 70, pp.109-117.

Brush, C.G., Carter, N.M., Gatewood, E.J., Greene, P.G. and Hart, M.M. (2006) 'The use of bootstrapping by women entrepreneurs in positioning for growth', Venture Capital, Vol. 8, No. 1, pp.15-31.

Bryman, A. (1995) Walt Disney and His World, Routledge, London.

Bryman, A. and Bell, E. (2003) Business Research Methods, Oxford University Press, Oxford.

Burt, R. (1992) Structural Holes: The Social Structure of Competition, Harvard University Press, Cambridge, MA.

Carter, N.M., Brush, C.G., Greene, P.G., Gatewood, E.J. and Hart, M.M. (2003) 'Women entrepreneurs who break through to equity financing: the influence of human, social and financial capital', Venture Capital, Vol. 5, No. 1, pp.1-28.

Crombac, G. (2001) Colin Chapman: The Man and His Cars, Haynes Publishing, Sparkford.

Dyson, J. (1997) Against the Odds, Texere Publishing, London.

Freear, J., Sohl, J.E. and Wetzel, W.E., Jr. (1995) 'Who bankrolls software entrepreneurs?', in Bygrave, W.D., Bird, B.J., Birley, S., Churchill, N.C., Hay, M., Keeley, R. and Wetzel, W.E., Jr. (Eds.): Frontiers of Entrepreneurship Research 1995, Babson College, Wellesley.

Hague, D. and Holmes, D. (2006) Oxford Entrepreneurs, CIHE, London.

Harrison, R.T., Mason, C.M. and Girling, P. (2004) 'Financial bootstrapping and venture development in the software industry', Entrepreneurship and Regional Development, Vol. 16, pp.307-333.

Jones, O. and Conway, S. (2004) 'The international reach of entrepreneurial networks: the case of James Dyson in the UK', in H. Etemad (Ed.): International Entrepreneurship in Small and Medium Enterprises: Orientation, Environment and Strategy, McGill International Entrepreneurship Series, Edward Elgar, Vol. 3, pp.87-106. 
Lawrence, M. (2002) Colin Chapman: Wayward Genius, Breedon Publishing, Derby.

Martin, J. and Siehl, C. (1983) 'Organizational culture and counterculture: an uneasy symbiosis', Organizational Dynamics, Autumn, pp.52-64.

Roberts, B. (2002) Biographical Research, Open University Press, Buckingham.

Sørheim, R. (2003) 'The pre-investment behaviour of business angels: a social capital approach', Venture Capital, Vol. 5, No. 4, pp.337-364.

Thorne, J.R. (1989) ‘Alternative financing for entrepreneurial ventures’, Entrepreneurship Theory and Practice, Spring, pp.7-9.

Van Auken, H. (2005) 'Differences in the usage of bootstrap financing among technology-based versus nontechnology-based firms', Journal of Small Business Management, Vol. 43, No. 1, pp.93-103.

Van Auken, H. and Neeley, L. (1996) 'Evidence of bootstrap financing among small start-up firms', Journal of Entrepreneurial and Small Business Finance, Vol. 5, No. 3, pp.235-250.

Van Osnabrugge, M. and Robinson, R.J. (2000) Angel Investing: Matching Start-up Funds with Start-up Companies - The Guide for Entrepreneurs, Individual Investors and Venture Capital, Jossey-Bass, San Francisco.

Winborg, J. and Landström, H. (1997) 'Financial bootstrapping in small businesses - a resource-based view on small business finance', in Reynolds, P.D., Bygrave, W.D., Carter, N.M., Davidsson, P., Gartner, W.B., Mason, C.M. and McDougall, P.P. (Eds.): Frontiers of Entrepreneurship Research 1997, Babson College, Wellesley, MA, pp.471-485.

Winborg, J. and Landström, H. (2001) 'Financial bootstrapping in small businesses: examining small business managers' resource acquisition behaviours', Journal of Business Venturing, Vol. 16, No. 3, pp.235-254.

Wood, A. (2001) Magnetic Venture: The Oxford Instruments Story, Oxford University Press, Oxford. 